\title{
Factors determining the soil health card adoption behaviour among farmers in Andhra Pradesh
}

\author{
K. Ragavendra Chowdary, M. Jayalakshmi and G. Prasadbabu
}

MEMBERS OF RESEARCH FORUM:

Corresponding author :

K. Ragavendra Chowdary, Krishi

Vigyan Kendra (ANGRAU), Banavasi,

Kurnool (A.P.) India

Co-authors :

M. Jayalakshmi and

G. Prasadbabu, Krishi Vigyan

Kendra (ANGRAU), Banavasi,

Kurnool (A.P.) India
Received : 00.00.2018; Revised : 00.00.2018; Accepted : 00.00 .2018

\section{Summary}

The soil health card (SHC) is used to assess the current status of soil health and when used over time, helps to determine changes in soil health that are affected by land management. A SHC displays soil health indicators and associated descriptive terms. The SHC carries cropwise recommendations of nutrients / fertilizers required for farms, making it possible for farmers to improve productivity by using appropriate inputs. The Central Government is providing assistance to State Governments for setting up soil testing laboratories for issuing such SHCs to farmers. State Governments have adopted innovative practices like involvement of agricultural students, NGOs and private sector in soil testing, determining average soil health of villages, etc., to issue SHCs. Though quite a few states including Tamil Nadu, Gujarat, Andhra Pradesh and Haryana are successfully distributing such cards, the Centre plans to make it a pan India effort. According to a data, till November $15^{\text {th }} 2017$, over 9.72 crore soil health cards have been issued to farmers to make them aware about nutrient deficiencies in their fields.

Key words : Soil health card, Behaviour among farmers

How to cite this article : Chowdary, K. Ragavendra , Jayalakshmi, M. and Prasadbahu, G. (2018). Factors determining the soil health card adoption behaviour among farmers in Andhra Pradesh. Asian J. Soil Sci., 13 (1) : 000-000 : DOI : 10.15740/HAS/AJSS/13.1/000-000. Copyright@ 2018: Hind AgriHorticultural Society.

\section{Adoption of soil health management practices:}

Sathyanarayanan (1991) indicated that about twothirds of the respondents $(63.33 \%)$ were medium level adopters of Azospirillum, followed by low adopters $(20.00 \%)$ and the rest were high adopters $(16.67 \%)$. Theodore (1998) in his study on contingency rice farming practices found that nearly half $(45.0 \%)$ of the contact farmers were high level adopters, while it was less than one-third (30\%) in case of other farmers. According to Woldeamlak (2007) and Tesfaye (2011), adoption of soil conservation structures is a difficult concept to measure. The structures can be considered as adopted if the land users continue to utilize them after the external assistance is withdrawn. Although adoption of the new technologies can be effectively evaluated only after the termination of the project, it can also be assessed by analyzing farmers' attitudes, objectives and desires of whether they would like to use the technologies as a part of their farming enterprise.

\section{Factors determining the adoption of soil health management practices:}

Cramb et al. (1999) found that household-level cash flow, rather than access to labour, was considered to be 
a more important explanatory factor for adoption of soil conservation practices. As per FAO (2001) and Pannell et al. (2006), adoption of agricultural technologies is usually influenced by several factors, among them, adopters own skill level and the abilities of farmers are critical determinant factors in adoption of agricultural technologies.

Long (2003) and Habtamu (2006) have opined that perceiving the soil erosion problem, and positive effect of soil conservation measures provide stimulus to and shapes opinions about adoption of conservation practices that stops the problem. In a study of programmatic approaches to successful adoption of soil and water conservation (SWC) practices in Southern Mali, Bodnár et al. (2006) found that farmers take several steps to learn about and accept innovations before they adopt them. First, they must have an awareness of particular problems affecting their land (i.e., recognizing soil erosion symptoms or water quality impairments) and they must be willing to undertake measures to correct the root problem(s) that cause such problems. Farmers then need to recognize what the possible solutions are and be able to acquire the skills to install these corrective measures. Most importantly, they need to believe in the potential benefits of SWC practices implementation before any are undertaken.

Wubuneh and Sanders (2006) have mentioned shortage of livestock to be a constraint for the uptake of inorganic fertilizers and new cultivars. Further, they indicated that livestock is very crucial in a farming system as they are a major source of manure and draft power. Marenya and Barett (2007) have reported that educational level as one of the factors immensely influencing adoption of ISFM. The main reason for this is that ISFM practices are knowledge-intensive and thus, require considerable management input. According to Dutta (2009) and Sabo (2007), ownership of livestock contributes to wealth status and wealthier farmers are likely to have more motivation to adopt ISFM and to continue to seek for and access relevant information using various channels so as to cater for their information needs.

Kibemo (2011) has opined that adoption of soil conservation technologies is considerably influenced by different factors. Among other influences, the characteristics of farmers such as age, education, household size, farm size and experience are some of the major influencing factors for the decision of application of soil conservation practices. Bayard et al. (2006) studied the adoption and management of soil conservation practices in Haiti. In this study he identified the factors which played a significant role in the management of this land improvement technology. In their findings, it was discovered that age, education, group membership and per capita income negatively influence the adoption and management of soil conservation practices.

\section{Constraints in adoption of soil health management practices:}

According to Wubneh and Sanders (2006), livestock is also very crucial in a farming system as they are a major source of manure and draft power. The more livestock a farmer has, the higher the possibility of the cost-effective use of manure to replenish soil fertility. Shortage of livestock has been mentioned as a constraint to the uptake of organic fertilizers and new cultivars. Damisa and Igonoh (2007); Odendo et al. (2006); Rege (2006) and Sanginga and Woomer (2009), have expressed that lack of access to reliable and current information coupled with wide communication gaps between researchers and farmers are presently a major impediment to adoption of ISFM by farmers in the Western Kenya region.

Ofuoku et al. (2008) and Sanginga and Woomer (2009) have stated that the low level of literacy among smallholder farmers in Sub-Saharan Africa (SSA) has been identified as a major constraint to effective communication and dissemination of soil fertility information, thus, acting as a major impediment to its access by farmers. Bennett and Cattle (2014) identified series of statements concerning impediments for the adoption of soil health management plans. These statements were separated into six broad categories: education and training impediments; agency and extension organization-based impediments; land-use associated impediments; market impediments; economic impediments and personal and social impediments.

\section{Suggestions to enhance adoption of soil health management practices:}

Adolwa et al. (2010) suggested that communitybased and mass media channels were most suitable for conveying ISFM information and knowledge to farmers. Farmer field 0days and other community-based communication channels which have been used 
extensively by stakeholders have their advantages and should continue to be promoted in the application of ISFM in Western Kenya. However, there is a need for researchers, extension workers and policy-makers to consider exploiting the use of community FM Radio Stations to promote the application of ISFM in the region as they have largely been utilized despite the numerous advantages of radio.

Bennett et al. (2014) suggest that there are three main areas for consideration in improving the adoption of structured soil health management programmes: ongoing communication and support; the initial cost of programme implementation and the availability and expense of appropriate machinery. Accordingly, targeting incentives and future efforts towards these three considerations would presumably increase the adoption and permanence of structured soil health management plans. A focus on providing ongoing technical and expert advice through future extension efforts should occur, while a central information portal, not unlike the soil health knowledge bank, would also be advantageous. The creation of a research register where scientists can upload information on current and completed research would allow other rural stakeholders the opportunity to remain in connection with current research.

Gwandu et al. (2014) in their research on factors influencing access to ISFM information and knowledge and its uptake among smallholder farmers in Zimbabwe, suggested that comprehensive training offered jointly to farmers and government extension officers through various iterative capacity building initiatives embraced in the learning-centred approach resulted in outcomes suggestive of successful involvement of farmers in knowledge and persuasive stages of the innovationdecision process. Thus, this study demonstrated the superiority of farmer access and use of ISFM information and attracting participation of different farmer categories.

\section{Literature Cited}

Bayard, B., Jolly, C. M. and Shannon, D. (2006). The adoption and management of soil coservation practices in Haiti: The case of Rock Walls. Agric. Econ. Rev., 7(2): 28-39.

Bennett, J., Mc, L. and Cattle, S.R. (2014). Adoption of soil health improvement strategies by Australian farmers: II. Impediments and incentives, J. Agric. Edu. \& Extn., 20 (1): 107-131.

Bodnar, F., Schrader, T. and Van Campen, W. (2006). How project approach influences adoption of soil and water conservation by farmers; examples from Southern Mali. Land Degradation \& Develop., 17: 479-494.

Brewin, D. (1982). Farmers perception of group conservation programmes and soil conservation Practices. Rural Extn. \& Training Abst., 5 (2): 601.

Cramb, R.A., Garcia, J.N.M., Gerrits, R.V. and Saguiguit, G.C. (1999). Smallholder adoption of soil conservation technologies : evidence from upland projects in the Philippines. Land Degradation \& Develop.,10: 405-423.

Damisa, M.A. and Igonoh, E. (2007). An evaluation of the adoption of integrated soil fertility management practices among women farmers in Danja, Nigeria. J. Agric. Edu. \& Extn., 13 (2) : 107-116.

Donovan, M.C. (1982).Achieving cost effective conservation. J. Soil \& Water Conserv., 37 (5) : 262-265.

Dutta, R. (2009). Information needs and information-seeking behaviour in developing countries: A Review of the Research. Internat. Inform. \& Library Rev., 41 : 44-51.

FAO (2001). The economics of conservation agriculture. Rome: Food and Agriculture Organization of the United Nations.

Gwandu, T., Mtambanangwe, F., Mapfumo, P., Mashavave, T., Chikowo, R. and Nezomba, H. (2014). Factors influencing access to integrated soil fertility management information and knowledge and its uptake among smallholder farmers in Zimbabwe, J. Agric. Edu. \& Extn., 20 (1): 79-93.

Habtamu, E. (2006). Adoption of physical soil and water conservation structures in anna watershed, Hadiya Zone. M.A. Thesis, Addis Ababa University Addis Ababa, Ethiopia.

Kibemo, Detamo Aga (2011). Farmers' perception on soil erosion and their use of structural soil conservation measures in Soro district, Southern Ethiopia, M.Sc. (Geo.\&.Ensc.) Thesis, Addis Ababa University, Addis Ababa.

Long, L. (2003). Conservation practices adoption by Agricultural Land Owners. Ph.D. Thesis, Northern Illinois University, Delealb, Illinois.

Marenya, P.P. and Barett, C.B. (2007). Household-level determinants of adoption of improved natural resources management practices among smallholder farmers in Western Kenya. Food Policy, 32: 515-336.

Odendo, M. J., Bationo, A. Ojiem and Mudeheri, M. (2006). On-farm evaluation and scaling-up of soil fertility management technologies in Western Kenya. Nutr. Cycling Agroeco Syst., 76:369-381.

Ofuoku, A.U., Emah, G.N. and Itedjere, B.E. (2008). Information utilization among rural fish farmers in Central Agricultural Zone of Delta state, Nigeria. World J. Agric. Sci., 
$4(5): 558-564$.

Pannell, D.J., Marshall, G.R., Barr, N., Curtis, A., Vanclay, F. and Wilkinson, R. (2006). Understanding and promoting adoption of conservation practices by rural landholders. Australian J. Exp.Agric.,46(11): 1407-1424.

Rege, R. (2006). Harnessing institutional alliances and partnerships in agricultural information systems in Kenya. Quarterly Bulletin of IAALD, 51(4): 215-222.

Sabo, E. (2007). Agricultural information needs of women farmers of Mumbi region, Adamawa State. J. Tropi. Agric., 45 (1-2): 69-71.

Saliba and Bromley, D. (1986). Soil management decisions: How they be compared and what variables influence them. North Central J. Agric. Econ., 8 (2): 305-317.

Sanginga, N. and Woomer, P.L. (2009). Integrated soil fertility management in Africa: principles, practices and developmental process. Nairobi: Tropical Soil Biology and Fertility Institute of the International Centre for Tropical Agriculture.

Sathyanarayanan, L. (1991). Technology generation and transfer by RRS, Paiyur and the acceptance by the farmers of North-Western Zone of Tamil Nadu. M.Sc. (Ag.) Thesis, Tamil Nadu Agricultural University, Coimbatore, T.N. (India).
Tesfaye, G. (2011). Adoption of structural soil and water conservation technologies by small holder farmers in Adama Wereda, East Shewa, Ethiopia. Internat. J. Adv, Structures \& Geotechnical Engg., 2 (2) : 58-68.

Theodore, Ravi Kumar (1988). Awareness, conviction and adoption of technological units of contingency farming practices for rice by contact and other farmers of Thanjavur district, M.Sc. (Ag.) Thesis, Tamil Nadu Agricultural University, Coimbatore, T.N. (India).

Woldeamlak, B. (2007). Soil and water conservation intervention with conventional technologiesin North-western Highlands of Ethiopia: Acceptance and adoption by farmers, Land Use Policy, 24 (2): 404-416.

Wubneh, N.G. and Sanders, J.H. (2006). Farm-level, adoption of sorghum in Tigray, Eithiopia. Agric. Syst., 91(1-2):122-134.

\section{Webliography}

Adolwa, I.S., Esilaba, A.O., Okoth, P.O. and Mulwa, M.R. (2010). Factors influencing uptake of integrated soil fertility management knowledge among smallholder farmers in Western Kenya. Paper presented at the $12^{\text {th }}$ KARI Biennial Conference, 8-12 November. http://www.Kari.org/biennialconference/ conference12/docs/Contents.htm. 